\title{
Can existing drugs approved for other indications retard renal function decline in patients with type 1 diabetes and nephropathy?
}

\author{
Alessandro Doria $^{1,2}$, Monika A. Niewczas ${ }^{1,2}$, and Paolo Fiorina ${ }^{2,3,4}$ \\ ${ }^{1}$ Section on Genetics and Epidemiology, Joslin Diabetes Center, Boston \\ ${ }^{2}$ Harvard Medical School, Boston, USA \\ ${ }^{3}$ Transplantation Research Center (TRC), Nephrology Division, Children's Hospital and Brigham \\ and Women's Hospital \\ ${ }^{4}$ San Raffaele Scientific Institute, Milan, Italy
}

\section{Abstract}

\begin{abstract}
Mounting evidence from human, animal, and in vitro studies indicates that existing drugs, developed to treat other disorders, might also be effective in preventing or slowing the progression of diabetic nephropathy to end stage renal disease. Examples of such drugs include the uratelowering agent allopurinol, the anti-TNF agents etanercept and infliximab, and the immunomodulating drug abatacept. Since some these medications are already on the market and have been used for a number of years for other indications, they can be immediately tested in humans for a beneficial effect on renal function in diabetes. Special emphasis should be placed on evaluating the use of these drugs early in the course of diabetic nephropathy when renal damage is most likely to be reversible and interventions can yield the greatest delay to end stage renal disease.
\end{abstract}

\section{Keywords}

diabetic nephropathy; uric acid; inflammation; immune system; novel therapeutics

\section{Introduction}

Diabetic nephropathy is the long-term complication of diabetes that imposes the highest social and economic burden, being one of the main causes of end stage renal disease (ESRD). ${ }^{1}$ Despite improvements in glycemic and blood pressure control, and the introduction of renin-angiotensin system (RAS) blockers, the overall risk of diabetic

(C) 2012 Elsevier Inc. All rights reserved.

Address for correspondence: Alessandro Doria, MD, PhD, MPH, Section on Genetics and Epidemiology, Joslin Diabetes Center, One Joslin Place, Boston, 02215, MA, USA, Tel: 617-309-2406, Fax: 617-309-2667, alessandro.doria@ joslin.harvard.edu, or, Paolo Fiorina, MD PhD, Transplantation Research Center, Nephrology Division, Children's Hospital, Harvard Medical School, 300 Longwood Ave., Enders $5^{\text {th }}$ floor, Room En530, Boston, 02215, MA, USA, Tel: 617-919-2624, Fax: 617-732-5254, paolo.fiorina@childrens.harvard.edu.

Publisher's Disclaimer: This is a PDF file of an unedited manuscript that has been accepted for publication. As a service to our customers we are providing this early version of the manuscript. The manuscript will undergo copyediting, typesetting, and review of the resulting proof before it is published in its final citable form. Please note that during the production process errors may be discovered which could affect the content, and all legal disclaimers that apply to the journal pertain. 
nephropathy in the population is not declining. ${ }^{2-4}$ Thus, novel therapeutic approaches are urgently needed to complement glycemic control and RAS inhibition.

One approach is to identify novel drug targets by gaining a better understanding of the pathogenesis of diabetic nephropathy at the molecular level, as discussed by other articles in this issue ${ }^{5-7}$. However, going from the identification of a drug target to the development of a clinically effective intervention is a long and costly process and only a small number of compounds that enter the development pipeline end up being approved for clinical use. The process is further complicated in the case of diabetic nephropathy by the lack of good animal models, as discussed by Breyer in this issue ${ }^{8}$.

A complementary strategy is to investigate whether existing drugs, developed and approved for other indications, may have as yet unknown therapeutic effects on diabetic nephropathy. The most obvious advantage of this approach is that clinical trials of these drugs, if justified, can be started at once. Other benefits include the extensive postmarketing surveillance conducted for many of these compounds, reducing the possibility of unknown side effects, and the fact that some of these drugs are inexpensive owing to their long presence on the market and their availability as generic preparations.

Some examples of existing drugs that could be tested for a beneficial effect on diabetic nephropathy are reported in Table 1 . Below we examine the evidence suggesting that these medications might be effective in preventing or slowing down kidney damage in diabetes and discuss how clinical trials of these drugs should be designed in order to maximize their probabilities of success.

\section{Drugs targeting metabolic pathways}

One possible strategy is to target metabolic pathways that are not involved in the etiology of diabetic nephropathy, but modulate the susceptibility of the kidney to the deleterious effects of hyperglycemia. Existing interventions in this category that have been investigated in clinical trials include B-vitamins, to decrease homocystinemia ${ }^{9-11}$, and statins, to decrease cholesterolemia $^{12,13}$. While neither of these treatments has yielded the expected benefits ${ }^{14-17}$, new hope for such adjuvant therapies has recently come from the finding of a link between uric acid and progression of kidney damage in diabetes.

In the Second Joslin Kidney Study (JKS), elevated baseline serum uric acid was one of the strongest independent predictors of early GFR in diabetes ${ }^{18}$. In this prospective study, including 355 Joslin patients with micro- or high-normoalbuminuria and estimated GFR $\geq$ $60 \mathrm{ml} / \mathrm{min}$ at baseline, a direct dose-response relationship was observed between baseline serum uric acid levels and subsequent risk of early increased GFR loss, defined as a rate of GFR decline above the $97.5^{\text {th }}$ percentile of the distribution in the general population (Figure 1). The unadjusted odds ratio was 1.5 (95\% CI $1.3-1.9, \mathrm{p}=0.0002)$ for each $\mathrm{mg} / \mathrm{dl}$ increase in serum uric acid, which translates into a $\sim 2$-fold increase in the risk of early GFR loss for a serum uric acid levels $\geq 5 \mathrm{mg} / \mathrm{dl}$ as compared to levels $<5 \mathrm{mg} / \mathrm{dl}$. The magnitude of this effect did not significantly change after adjustment for urinary AER, gender, HbA1c, or, importantly, baseline GFR. Serum uric acid also predicted the transition from normoalbuminuria to micro- or macro-albuminuria in the Coronary Artery Calcification in Type 1 Diabetes Study ${ }^{19,20}$. As in the JKS, the effect of uric acid was not influenced by adjustment for other baseline variables. Similarly, in a study from Denmark, the uric acid level shortly after the onset of type 1 diabetes was a significant independent predictor of macroalbuminuria 18 years later ${ }^{21}$.

The prospective nature of these findings and their robustness to adjustment for potential confounders strongly suggest that moderately elevated serum uric acid may play a causal 
role by favoring the deterioration of kidney function caused by the diabetic milieu.

Alterations of nitric oxide (NO) pathways and induction of pro-inflammatory cytokines ${ }^{22,23}$, and increased oxidative stress resulting from the generation of uric acid by xanthine oxidase $^{24,25}$ could be responsible for this effect. Two small clinical trials have recently provided proof of concept data for translating these findings into a novel intervention. One of these study was from Hong-Kong and included 51 subjects (25\% of whom with diabetes) having CKD Stage 3 or higher, who were treated with allopurinol for 12 months ${ }^{26}$. At the end of the intervention, about $20 \%$ of individuals in the allopurinol group had had a significant increase in serum creatinine as opposed to about $70 \%$ in the placebo group. The other study was from Spain and included 113 subjects with CKD stage 3 or higher, who were treated with allopurinol for 24 months ${ }^{27}$. About $15 \%$ of the participants had diabetes. During the trial, GFR increased by $1 \mathrm{ml} / \mathrm{min}$ in the allopurinol group as compared to a $3 \mathrm{ml} /$ min loss in the placebo group. A beneficial effect of urate-lowering drugs on the progression of kidney disease has also been observed in animal models ${ }^{28}$.

The availability of a safe and inexpensive uric acid-lowering drug such as allopurinol makes this intervention especially attractive. Allopurinol is an inhibitor of xanthine oxidase, which is responsible for the conversion of hypoxanthine to xanthine and of xanthine to uric acid. It has been on the market since 1964 as the main drug for the prevention of gout in hyperuricemic subjects and the prevention of acute urate nephropathy and gout in patients receiving chemotherapy for cancer. At the average dosage (300 mg/day), allopurinol causes a $30-40 \%$ reduction in serum $\mathrm{UA}^{29-31}$, but up to a $60 \%$ reduction can be obtained using the maximum dosage of $600 \mathrm{mg} .{ }^{32}$ Skin rashes, usually maculopapular, are the most commonly reported adverse effect. Rashes may be followed by more severe hypersensitivity reactions such as exfoliative lesions and the Stevens-Johnson syndrome, but such occurrence is very rare, in the order of 1 in $10,000^{33}$. Other potential adverse effects include gout flares (if there is a history of gout), hepatotoxicity, and, rarely, bone marrow depression. A new uric acid-lowering drug (febuxostat) that does not have the skin side effects of allopurinol has become recently available ${ }^{30}$, although its cardiovascular safety is still being investigated (NCT01101035).

\section{Drug targeting inflammatory pathways}

Inflammation, as indicated by the presence of inflammatory cells in the tubulointerstitium, has been known for many years to occur in the diabetic kidneys. Indeed, a number of studies have shown that in diabetic subjects the degree of tubulointerstitial injury correlates better with the impairment of renal function than the degree of glomerular damage ${ }^{34-36}$. In agreement with these findings, prospective studies have shown that increase urinary levels of tubular and inflammatory markers such as kidney injury molecule-1 (KIM1) and monocyte chemotactic protein-1 (MCP-1) accompany the progression of diabetic nephropathy 37,38 . The demonstration in animal models that lymphocytes are not essential for these changes points to a key role of innate immunity in this process ${ }^{39}$ and suggests that drugs targeting these pathways could exert a beneficial effect in preserving renal function in diabetes.

Macrophages are the major inflammatory cells infiltrating the kidney in diabetic nephropathy ${ }^{40}$. Accumulation and activation of these cells have been described in the kidneys of $\mathrm{db} / \mathrm{db}$ mice with proteinuria, their extent being correlated with hyperglycemia, HbA1c levels, albuminuria, elevated plasma creatinine, glomerular and tubular damage, renal fibrosis, and kidney expression of macrophage chemokines ${ }^{41}$. Interestingly, some of the beneficial effects of drugs commonly used in diabetes appear to result from their capacity to interfere with macrophage functions. For instance, angiotensin II receptor blockers and ACE inhibitors reduce macrophage-mediated injury in diabetic nephropathy by 
down-regulating macrophage NF-kB signaling ${ }^{42}$. Other agents that interfere with macrophage functions could be similarly useful to prevent diabetic nephropathy. An example is MMF - an immunosuppressant that was shown to inhibit kidney macrophage accumulation and diabetic nephropathy severity in Zucker rats ${ }^{43}$. An especially attractive target is MCP-1 - a chemokine having potent chemoattractive effects on macrophages. Inhibition of MCP-1 or its receptor reduces interstitial inflammation and macrophage accumulation in experimental models of diabetes ${ }^{4-46}$. An MCP-1 inhibitor - Bindarit - has been demonstrated to reduce albuminuria in active lupus nephritis ${ }^{47}$ and a phase II study of this drug in albuminuric subjects with type 2 diabetes has just been completed (NCT01109212), although results have not been made public yet.

Another strategy is to use drugs acting on the development of interstitial fibrosis, the sequela of inflammation that is in the end responsible for the loss of kidney function. One such drug is pirfenidone - an inhibitor of TGF- $\beta$ production that has been shown to decrease matrix deposition in experimental models of kidney disease ${ }^{48}$. In a small, exploratory study, this compound had beneficial effects on GFR decline in both type 1 and type 2 diabetic subjects with advanced diabetic nephropathy, but these findings must be validated in larger studies ${ }^{49}$.

Additional suggestions about possible targets are expected from epidemiological studies. In this regard, a recent cohort study including over a thousand patients with both types of diabetes attending the Joslin Clinic has shown that elevated circulating levels of TNF receptors 1 and 2 are strong, independent predictors of subsequent kidney function loss ${ }^{50,51}$. The predictive power of these two inflammatory markers was much stronger than that of other markers of endothelial dysfunction and inflammation or other components of the TNF pathway including TNFa itself. The role of TNFa is well recognized in the etiology of rheumatoid arthritis and TNFa inhibitors, such as etanercept or infliximab, are routinely used in the treatment of this disease ${ }^{52}$. There is also a body of literature supporting a role of $\mathrm{TNFa}$ in the etiology of diabetic nephropathy ${ }^{53}$. However, the findings from the Joslin study raise the question as of whether interventions in diabetic nephropathy should be specifically focused on TNF receptors rather than on the TNF pathway in general. In support of this hypothesis, in vitro exposure of human kidney cells to soluble TNF receptors triggers cell death even in the absence of TNF $a$ in the medium ${ }^{54}$. Furthermore, TNFR1 and TNFR2 knockout mice show a delay in the fibrotic response in experimental models of tubulointerstitial fibrosis ${ }^{55}$. A new antagonist of TNF receptors (progranulin), inhibiting the interaction between TNFa and TNFRs in a dose-dependent manner, has been recently identified through a global genetic screening ${ }^{56}$. This molecule and its engineered derivative Atsttrin have been shown to delay the course of rheumatoid arthritis in animal studies ${ }^{57}$. Thus, one can hypothesize that TNFR inhibition may become an attractive therapeutic tool to evaluate for the prevention of ESRD in diabetes in the near future.

\section{Drug targeting immunological mechanisms}

While diabetic nephropathy has never been considered an immunological disease, several reports in the literature have recently raised the possibility that immune-related mechanisms may be involved in its pathogenesis ${ }^{58,59}$.

$\mathrm{T}$-cells have been found in the kidneys of animal models of diabetic nephropathy ${ }^{60}$, probably recruited into this organ by the overexpression of MCP-1, CX3CL1, and ICAM-1 by inflamed endothelial cells ${ }^{61}$. Since T-cell depletion affects the development and the natural history of renal damage in animal models ${ }^{62}$, drugs that target these cells (e.g., anti$\mathrm{CD} 3 \mathrm{mAb}$ or ATG) or abrogate their proliferation/activation may have a use for diabetic nephropathy, even though they should probably be reserved to high risk patients (e.g.; fast decliners) given the potential for severe adverse events ${ }^{63}$. Interventions targeting B-cells are 
also available, but the evidence for a role of these cells in diabetic nephropathy is not as clear cut as for T-cells.

In addition to immune cells infiltrating the kidney, a variety of immune-related molecules have been found to be expressed by non-immune cells such as podocytes, mesangial cells, and tubular cells and to be upregulated in response to high-glucose or other stresses. For instance, Gutwein et al. found that cytokines such as IFN- $\gamma$ and TNF-a induce podocyte expression of CXCL16 and ADAM10, which may in turn chemoattract T-cells ${ }^{64}$. Also, Huber et al. demonstrated that human podocytes, either grown in culture or isolated from biopsies, express many chemokines' receptors, including CCR4, CCR8, CCR9, CCR10, CXCR1, CXCR3, CXCR4, and CXCR5 ${ }^{65}$. Podocytes also express CD80 (B7.1) in response to LPS and other types of stress, and lack of this molecule significantly reduces LPSmediated podocyte injury ${ }^{66}$. Studies are underway to determine whether podocytes respond in a similar way to high glucose. If this is the case, one could hypothesize the use of CTLA4-Ig (Abatacept) - a molecule that binds and blocks B7.1 on podocytes - as a therapeutic approach to diabetic nephropathy. This drug has been safely tested in patients with new onset type 1 diabetes in a study aimed at delaying C-peptide loss ${ }^{67}$. In this multicenter trial, patients with recently diagnosed type 1 diabetes were randomly assigned to abatacept $(10 \mathrm{mg} / \mathrm{kg})$ or placebo administered intravenously on days $1,14,28$, and monthly for a total of 27 infusions over 2 years. Abatacept-treated subjects experienced few infusionrelated adverse events (22\% in patients on abatacept and $17 \%$ in those on placebo) and did no show any increase in the risk of infections ( $42 \%$ vs. $43 \%$ in the abatacept vs. the placebo group, respectively) or neutropenia (9\% vs. 14\%). Thus, abatacept seems to be as safe as placebo when used in mono-therapy. In view of these findings and the extensive clinical trials of Abatacept for immune-related kidney diseases (Table 2) and Belatacept (which differs from Abatacept by only 2 aminoacids and binds both CD80/B7.1 and CD86/B7.2) in kidney-transplanted patients, these drugs appear as the most attractive immuno-modulatory interventions for diabetic nephropathy. Of note, B7.1/CD80 and CD86/B7.2 are also expressed on human tubular cells during inflammation where they may interact with their ligand CD28, either soluble or expressed by T-cells, and lead to the loss or damage of tubular cells ${ }^{68}$. Thus, blockage of B7.1 and of B7.2 may also have a benefit at this level in addition to that on podocytes.

\section{Clinical trials to test the efficacy of existing drugs}

Since many of the drugs discussed above have been already approved for other indications, their effect on diabetic nephropathy can be readily tested in randomized clinical trials. It is crucial, however, that these trials are properly designed in order to maximize power and to exploit the full potential of these drugs to prevent or retard renal function loss.

\section{Target population}

One important aspect concerns the selection of the individuals to whom these interventions should be applied. As illustrated in detail in the introductory issue of this article ${ }^{69}$, the rate of renal function decline varies widely among the diabetic subjects who progress to ESRD, suggesting heterogeneity in the underlying mechanisms of kidney damage. It is also likely that the molecular pathways involved in the etiology of kidney damage undergo changes as the renal function declines from norml to ESRD. Thus, candidate drugs should be tested in specific groups of diabetic subjects defined on the basis of their rate of kidney function loss (e.g., rapid progressors vs. slow progressors) and their stage of renal function loss (e.g., early vs. late). For each drug, the group of patients to be targeted should be decided on the basis of the evidence from human and animal studies concerning the role of the drug target in the progression of kidney disease. 
Interventions that may be effective at the early stages of renal fucntion loss are especially attractive since these can yield the greatest delay to ESRD. If a diabetic patient loses GFR at a constant rate of $4 \mathrm{ml} / \mathrm{min}$ per year, a $50 \%$ reduction in that rate of decline will delay reaching ESRD (GFR $\leq 15 \mathrm{ml} / \mathrm{min}$ ) by 20 years if the intervention is started when the GFR is $90 \mathrm{ml} / \mathrm{min}$, as opposed to a delay of only 8 years if the intervention is started when the GFR is $45 \mathrm{ml} / \mathrm{min}$. For young type 1 diabetic patients with kidney complications, such as that depicted in Figure 2, this may make the difference between developing ESRD in their 70s as opposed to their 50s. A potential argument against early interventions is that a good proportion of the diabetic patients with mild to moderately decreased GFR may be "slow progressors" who will never reach ESRD. Thus, one may need to treat a large number of them to prevent ESRD in the relatively small proportion at risk. However, biomarkers, such as serum uric acid in the case of allopurinol ${ }^{18}$ or TNF receptors for drugs targeting the TNF system $^{50,51}$, are often available to identify individuals who are at greater risk of loosing GFR and would specifically benefit from the interventions under consideration. This is in addition to increased albuminuria, which can also be used to select higher risk candidates for early interventions.

\section{Response/outcome variable}

Past clinical trials of therapies for diabetic nephropathy have often used albuminuria as the response variable. However, prospective studies have shown that, in a substantial proportion of type 1 diabetes patients, there may be a dissociation between natural history of renal function and that of albuminuria. ${ }^{70-72}$ Since it is the loss of renal function that drives the increased morbidity and mortality associated with diabetic nephropathy, it seems obvious that this, rather than albuminuria, should be the outcome on which the efficacy of an intervention is measured. If the goal is to intervene early, as we have argued in the previous paragraph, the most effective response variable would be the GFR at the end of the intervention considered on a continuous scale after adjustment for the baseline value. This approach is equivalent to comparing pre- to post-treatment changes in GFR between treatment arms, but yields greater power when the correlation between pre- and posttreatment values is only moderate ${ }^{73}$. A related approach is to measure the GFR at different time points in order to estimate the slope of GFR decline during the intervention period. The problem with this strategy, however, is that GFR slopes may be unduly influenced by transitory changes in the GFR early in the course of treatment as discussed by Stevens et al. ${ }^{74}$. Furthermore, the methods for comparing slopes are more complex, since they involve the analysis of time $\times$ treatment interactions. Such complexity may offset the gain in power provided by the multiple GFR measures. Survival analyses based on hard endpoints, such as ESRD or serum creatinine doubling, are not useful for the study of interventions on early GFR loss since an extremely long trial duration and large sample size would be required in order to have enough events for a meaningful comparison between treatment arms. For instance, an untreated patients having a baseline GFR of $80 \mathrm{ml} / \mathrm{min}$ and losing GFR at a constant rate of $4 \mathrm{ml} / \mathrm{min} /$ year would need 12 years to experience a doubling of serum creatinine and 17 years to reach ESRD. It should be added that it is not strictly necessary to demonstrate efficacy on hard endpoints in the case of drugs that are already on the market and for which there is no interest in applying to the FDA for a new indication. If such evidence is needed, as in the case of a new drug, one approach can be to restrict the study population to subjects who have a GFR closer to the end-point and are at especially high risk of losing renal function based their previous clinical history or biomarker profile.

\section{Time frame}

Another important aspect concerns the optimal duration of the trial. Many of the trials conducted thus far have been relatively short, mostly being less than two year long, in order to minimize attrition and contain financial and human costs. However, it is critical that trials 
are long enough to go beyond functional, short-term effects that drugs may have on GFR ${ }^{74}$. Even more importantly, the longer is the trial, the larger are the differences in GFR that can be attained between treatment arms, increasing the power of the study for any given sample size.

\section{Summary and conclusions}

Despite the progress that has occurred during the pat 20 years, preventing end stage renal disease in diabetes is still an unmet need. While research is ongoing to develop new medications, several drugs that are already on the market for the treatment of metabolic, inflammatory, and immunological disorders can be hypothesized to have beneficial effects on diabetic nephropathy based on the known links between their molecular targets and kidney damage in diabetes. Given their known safety profile, some of these drugs could and should be immediately tested for a beneficial effect on kidney function in humans. In doing so, we should take the opportunity to rethink the design of diabetic nephropathy clinical trials in order to increase power and maximize the impact of interventions on the natural history of kidney disease in diabetes.

\section{Acknowledgments}

Part of this work was supported by NIH grant R03 DK094484 (A.D.) and MIUR grant "Staminali" RFFSR-2008-1213704 (P.F.). P.F. is the recipient of a JDRF-Career Development Award and an ASN Career Development Award. MAN is the recipient of ADA mentor-based fellowship 7-03-MN-28 and Joslin DRC P\&F grant 2011.

\section{Reference List}

1. Krolewski, AS.; Warram, JH. Epidemiology of late complications of diabetes: A basis for the development and evaluation of preventive program. In: Kahn, CR.; Weir, GC.; King, GL.; Jacobson, AM.; Moses, AC.; Smith, RJ., editors. Joslin's Diabetes Mellitus. New York: Lippincott, Williams \& Wilkins; 2005

2. U S Renal Data System. Bethesda, MD: National Institutes of Health, National Institute of Diabetes and Digestive and Kidney Diseases; 2010. USRDS 2010 Annual Data Report: Atlas of Chronic Kidney Disease and End-Stage Renal Disease in the United States.

3. de Boer IH, Rue TC, Hall YN, Heagerty PJ, Weiss NS, Himmelfarb J. Temporal trends in the prevalence of diabetic kidney disease in the United States. JAMA. 2011; 305(24):2532-2539. [PubMed: 21693741]

4. Rosolowsky ET, Skupien J, Smiles AM, Niewczas M, Roshan B, Stanton R, et al. Risk for ESRD in type 1 diabetes remains high despite renoprotection. J Am Soc Nephrol. 2011; 22(3):545-553. [PubMed: 21355053]

5. Bonventre JV. Can we target tubular damage to prevent renal function decline in diabetes? Semin Nephrol. 2012 In press.

6. Humphrey B. Targeting pericyte differentiation as a strategy to modulate kidney fibrosis in diabetic nephropathy. Semin Nephrol. 2012 In press.

7. Mima A, Qi W, King GL. Implications of treatment that target protective mechanisms against diabetic nephropathy. Semin Nephrol. 2012 In press.

8. Breyer MD. Drug development for diabetic glomerular disease. Semin Nephrol. 2012 In press.

9. Looker HC, Fagot-Campagna A, Gunter EW, Pfeiffer CM, Narayan KM, Knowler WC, et al. Homocysteine as a risk factor for nephropathy and retinopathy in Type 2 diabetes. Diabetologia. 2003; 46(6):766-772. [PubMed: 12774164]

10. Buysschaert M, Dramais AS, Wallemacq PE, Hermans MP. Hyperhomocysteinemia in type 2 diabetes: relationship to macroangiopathy, nephropathy, and insulin resistance. Diabetes Care. 2000; 23(12):1816-1822. [PubMed: 11128359] 
11. Eikelboom JW, Lonn E, Genest J Jr, Hankey G, Yusuf S. Homocyst(e)ine and cardiovascular disease: a critical review of the epidemiologic evidence. Ann Intern Med. 1999; 131(5):363-375. [PubMed: 10475890]

12. Bonnet F, Cooper ME. Potential influence of lipids in diabetic nephropathy: insights from experimental data and clinical studies. Diabetes Metab. 2000; 26(4):254-264. [PubMed: 11011217]

13. Valensi P, Picard S. Lipids, lipid-lowering therapy and diabetes complications. Diabetes Metab. 2011; 37(1):15-24. [PubMed: 21126902]

14. House AA, Eliasziw M, Cattran DC, Churchill DN, Oliver MJ, Fine A, et al. Effect of B-vitamin therapy on progression of diabetic nephropathy: a randomized controlled trial. JAMA. 2010; 303(16):1603-1609. [PubMed: 20424250]

15. Colhoun HM, Betteridge DJ, Durrington PN, Hitman GA, Neil HA, Livingstone SJ, et al. Effects of atorvastatin on kidney outcomes and cardiovascular disease in patients with diabetes: an analysis from the Collaborative Atorvastatin Diabetes Study (CARDS). Am J Kidney Dis. 2009; 54(5):810-819. [PubMed: 19540640]

16. Sandhu S, Wiebe N, Fried LF, Tonelli M. Statins for improving renal outcomes: a meta-analysis. J Am Soc Nephrol. 2006; 17(7):2006-2016. [PubMed: 16762986]

17. Sukhija R, Bursac Z, Kakar P, Fink L, Fort C, Satwani S, et al. Effect of statins on the development of renal dysfunction. Am J Cardiol. 2008; 101(7):975-979. [PubMed: 18359317]

18. Ficociello LH, Rosolowsky ET, Niewczas MA, Maselli NJ, Weinberg JM, Aschengrau A, et al. High-normal serum uric acid increases risk of early progressive renal function loss in type 1 diabetes: results of a 6-year follow-up. Diabetes Care. 2010; 33(6):1337-1343. [PubMed: 20332356]

19. Jalal DI, Rivard CJ, Johnson RJ, Maahs DM, McFann K, Rewers M, et al. Serum uric acid levels predict the development of albuminuria over 6 years in patients with type 1 diabetes: findings from the Coronary Artery Calcification in Type 1 Diabetes study. Nephrol Dial Transplant. 2010; 25(6): 1865-1869. [PubMed: 20064950]

20. Rodrigues TC, Maahs DM, Johnson RJ, Jalal DI, Kinney GL, Rivard C, et al. Serum uric acid predicts progression of subclinical coronary atherosclerosis in individuals without renal disease. Diabetes Care. 2010; 33(11):2471-2473. [PubMed: 20798338]

21. Hovind P, Rossing P, Tarnow L, Johnson RJ, Parving HH. Serum uric acid as a predictor for development of diabetic nephropathy in type 1 diabetes: an inception cohort study. Diabetes. 2009; 58(7):1668-1671. [PubMed: 19411615]

22. Johnson RJ, Segal MS, Srinivas T, Ejaz A, Mu W, Roncal C, et al. Essential hypertension, progressive renal disease, and uric acid: a pathogenetic link? J Am Soc Nephrol. 2005; 16(7): 1909-1919. [PubMed: 15843466]

23. Mazzali M, Kanellis J, Han L, Feng L, Xia YY, Chen Q, et al. Hyperuricemia induces a primary renal arteriolopathy in rats by a blood pressure-independent mechanism. Am J Physiol Renal Physiol. 2002; 282(6):F991-F997. [PubMed: 11997315]

24. Desco MC, Asensi M, Marquez R, Martinez-Valls J, Vento M, Pallardo FV, et al. Xanthine oxidase is involved in free radical production in type 1 diabetes: protection by allopurinol. Diabetes. 2002; 51(4):1118-1124. [PubMed: 11916934]

25. Pacher P, Nivorozhkin A, Szabo C. Therapeutic effects of xanthine oxidase inhibitors: renaissance half a century after the discovery of allopurinol. Pharmacol Rev. 2006; 58(1):87-114. [PubMed: 16507884]

26. Siu YP, Leung KT, Tong MK, Kwan TH. Use of allopurinol in slowing the progression of renal disease through its ability to lower serum uric acid level. Am J Kidney Dis. 2006; 47(1):51-59. [PubMed: 16377385]

27. Goicoechea M, de Vinuesa SG, Verdalles U, Ruiz-Caro C, Ampuero J, Rincon A, et al. Effect of allopurinol in chronic kidney disease progression and cardiovascular risk. Clin J Am Soc Nephrol. 2010; 5(8):1388-1393. [PubMed: 20538833]

28. Sanchez-Lozada LG, Tapia E, Soto V, Avila-Casado C, Franco M, Wessale JL, et al. Effect of febuxostat on the progression of renal disease in 5/6 nephrectomy rats with and without hyperuricemia. Nephron Physiol. 2008; 108(4):69-78. 
29. Schumacher HR Jr, Becker MA, Wortmann RL, MacDonald PA, Hunt B, Streit J, et al. Effects of febuxostat versus allopurinol and placebo in reducing serum urate in subjects with hyperuricemia and gout: a 28-week, phase III, randomized, double-blind, parallel-group trial. Arthritis Rheum. 2008; 59(11):1540-1548. [PubMed: 18975369]

30. Becker MA, Schumacher HR Jr, Wortmann RL, MacDonald PA, Eustace D, Palo WA, et al. Febuxostat compared with allopurinol in patients with hyperuricemia and gout. N Engl J Med. 2005; 353(23):2450-2461. [PubMed: 16339094]

31. Feig DI, Soletsky B, Johnson RJ. Effect of allopurinol on blood pressure of adolescents with newly diagnosed essential hypertension: a randomized trial. JAMA. 2008; 300(8):924-932. [PubMed: 18728266]

32. Noman A, Ang DS, Ogston S, Lang CC, Struthers AD. Effect of high-dose allopurinol on exercise in patients with chronic stable angina: a randomised, placebo controlled crossover trial. Lancet. 2010; 375(9732):2161-2167. [PubMed: 20542554]

33. Roujeau JC, Kelly JP, Naldi L, Rzany B, Stern RS, Anderson T, et al. Medication use and the risk of Stevens-Johnson syndrome or toxic epidermal necrolysis. N Engl J Med. 1995; 333(24):16001607. [PubMed: 7477195]

34. Mauer M, Zinman B, Gardiner R, Suissa S, Sinaiko A, Strand T, et al. Renal and retinal effects of enalapril and losartan in type 1 diabetes. N Engl J Med. 2009; 361(1):40-51. [PubMed: 19571282]

35. Bohle A, Wehrmann M, Bogenschutz O, Batz C, Muller CA, Muller GA. The pathogenesis of chronic renal failure in diabetic nephropathy. Investigation of 488 cases of diabetic glomerulosclerosis. Pathol Res Pract. 1991; 187(2-3):251-259. [PubMed: 2068008]

36. Risdon RA, Sloper JC, De Wardener HE. Relationship between renal function and histological changes found in renal-biopsy specimens from patients with persistent glomerular nephritis. Lancet. 1968; 2(7564):363-366. [PubMed: 4173786]

37. Vaidya VS, Niewczas MA, Ficociello LH, Johnson AC, Collings FB, Warram JH, et al. Regression of microalbuminuria in type 1 diabetes is associated with lower levels of urinary tubular injury biomarkers, kidney injury molecule-1, and N-acetyl-beta-D-glucosaminidase. Kidney Int. 2011; 79(4):464-470. [PubMed: 20980978]

38. Wolkow PP, Niewczas MA, Perkins B, Ficociello LH, Lipinski B, Warram JH, et al. Association of urinary inflammatory markers and renal decline in microalbuminuric type 1 diabetics. $\mathrm{J}$ Am Soc Nephrol. 2008; 19(4):789-797. [PubMed: 18256362]

39. Lim AK, Ma FY, Nikolic-Paterson DJ, Kitching AR, Thomas MC, Tesch GH. Lymphocytes promote albuminuria, but not renal dysfunction or histological damage in a mouse model of diabetic renal injury. Diabetologia. 2010; 53(8):1772-1782. [PubMed: 20422398]

40. Tesch GH. Macrophages and diabetic nephropathy. Semin Nephrol. 2010; 30(3):290-301. [PubMed: 20620673]

41. Chow F, Ozols E, Nikolic-Paterson DJ, Atkins RC, Tesch GH. Macrophages in mouse type 2 diabetic nephropathy: correlation with diabetic state and progressive renal injury. Kidney Int. 2004; 65(1):116-128. [PubMed: 14675042]

42. Mizuno M, Sada T, Kato M, Fukushima Y, Terashima H, Koike H. The effect of angiotensin II receptor blockade on an end-stage renal failure model of type 2 diabetes. J Cardiovasc Pharmacol. 2006; 48(4):135-142. [PubMed: 17086090]

43. Rodriguez-Iturbe B, Quiroz Y, Shahkarami A, Li Z, Vaziri ND. Mycophenolate mofetil ameliorates nephropathy in the obese Zucker rat. Kidney Int. 2005; 68(3):1041-1047. [PubMed: 16105034]

44. Giunti S, Barutta F, Perin PC, Gruden G. Targeting the MCP-1/CCR2 System in diabetic kidney disease. Curr Vasc Pharmacol. 2010; 8(6):849-860. [PubMed: 20180766]

45. Tesch GH. MCP-1/CCL2: a new diagnostic marker and therapeutic target for progressive renal injury in diabetic nephropathy. Am J Physiol Renal Physiol. 2008; 294(4):F697-F701. [PubMed: 18272603]

46. Tesch GH, Lim AK. Recent insights into diabetic renal injury from the $\mathrm{db} / \mathrm{db}$ mouse model of type 2 diabetic nephropathy. Am J Physiol Renal Physiol. 2011; 300(2):F301-F310. [PubMed: 21147843] 
47. Ble A, Mosca M, Di Loreto G, Guglielmotti A, Biondi G, Bombardieri S, et al. Antiproteinuric effect of chemokine C-C motif ligand 2 inhibition in subjects with acute proliferative lupus nephritis. Am J Nephrol. 2011; 34(4):367-372. [PubMed: 21876349]

48. Shihab FS, Bennett WM, Yi H, Andoh TF. Pirfenidone treatment decreases transforming growth factor-betal and matrix proteins and ameliorates fibrosis in chronic cyclosporine nephrotoxicity. Am J Transplant. 2002; 2(2):111-119. [PubMed: 12099512]

49. Sharma K, Ix JH, Mathew AV, Cho M, Pflueger A, Dunn SR, et al. Pirfenidone for diabetic nephropathy. J Am Soc Nephrol. 2011; 22(6):1144-1151. [PubMed: 21511828]

50. Gohda T, Niewczas MA, Skupien J, Walker WH, Ficociello LH, Sciutto FR, et al. Circulating Tumor Necrosis Factor Receptors 1 and 2 and risk of Early Renal Function Decline in Type 1 Diabetes. J Am Soc Nephrol. 2011

51. Niewczas MA, Gohda T, Skupien J, Smiles AM, Walker WH, Sciutto FR, et al. Serum markers of Tumor Necrosis Factor Pathway And Risk of End-Stage Renal Disease in Type 2 Diabetes. J Am Soc Nephrol. 2011

52. McInnes IB, Schett G. The Pathogenesis of Rheumatoid Arthritis. New England Journal of Medicine. 2011; 365(23):2205-2219. [PubMed: 22150039]

53. Navarro JF, Mora-Fernandez C. The role of TNF-alpha in diabetic nephropathy: pathogenic and therapeutic implications. Cytokine Growth Factor Rev. 2006; 17(6):441-450. [PubMed: 17113815]

54. Al Lamki RS, Wang J, Vandenabeele P, Bradley JA, Thiru S, Luo D, et al. TNFR1- and TNFR2mediated signaling pathways in human kidney are cell type-specific and differentially contribute to renal injury. FASEB J. 2005; 19(12):1637-1645. [PubMed: 16195372]

55. Guo G, Morrissey J, McCracken R, Tolley T, Klahr S. Role of TNFR1 and TNFR2 receptors in tubulointerstitial fibrosis of obstructive nephropathy. American Journal of Physiology - Renal Physiology. 1999; 277(5):F766-F772.

56. Liu CJ, Bosch X. Progranulin: A growth factor, a novel TNFR ligand and a drug target. Pharmacol Ther. 2011

57. Tang W, Lu Y, Tian QY, Zhang Y, Guo FJ, Liu GY, et al. The Growth Factor Progranulin Binds to TNF Receptors and Is Therapeutic Against Inflammatory Arthritis in Mice. Science. 2011; 332(6028):478-484. [PubMed: 21393509]

58. Schlondorff D, Banas B. The mesangial cell revisited: no cell is an island. J Am Soc Nephrol. 2009; 20(6):1179-1187. [PubMed: 19470685]

59. Anders HJ, Muruve DA. The inflammasomes in kidney disease. J Am Soc Nephrol. 2011; 22(6): 1007-1018. [PubMed: 21566058]

60. Breyer MD, Bottinger E, Brosius FC III, Coffman TM, Harris RC, Heilig CW, et al. Mouse models of diabetic nephropathy. J Am Soc Nephrol. 2005; 16(1):27-45. [PubMed: 15563560]

61. Galkina E, Ley K. Leukocyte recruitment and vascular injury in diabetic nephropathy. J Am Soc Nephrol. 2006; 17(2):368-377. [PubMed: 16394109]

62. Eller K, Kirsch A, Wolf AM, Sopper S, Tagwerker A, Stanzl U, et al. Potential role of regulatory T cells in reversing obesity-linked insulin resistance and diabetic nephropathy. Diabetes. 2011; 60(11):2954-2962. [PubMed: 21911743]

63. Getts DR, Shankar S, Chastain EM, Martin A, Getts MT, Wood K, et al. Current landscape for Tcell targeting in autoimmunity and transplantation. Immunotherapy. 2011; 3(7):853-870. [PubMed: 21751954]

64. Gutwein P, Abdel-Bakky MS, Doberstein K, Schramme A, Beckmann J, Schaefer L, et al. CXCL16 and oxLDL are induced in the onset of diabetic nephropathy. J Cell Mol Med. 2009; 13(9B):3809-3825. [PubMed: 19426159]

65. Huber TB, Reinhardt HC, Exner M, Burger JA, Kerjaschki D, Saleem MA, et al. Expression of functional CCR and CXCR chemokine receptors in podocytes. J Immunol. 2002; 168(12):6244 6252. [PubMed: 12055238]

66. Reiser J, von GG, Loos M, Oh J, Asanuma K, Giardino L, et al. Induction of B7-1 in podocytes is associated with nephrotic syndrome. J Clin Invest. 2004; 113(10):1390-1397. [PubMed: 15146236] 
67. Orban T, Bundy B, Becker DJ, DiMeglio LA, Gitelman SE, Goland R, et al. Co-stimulation modulation with abatacept in patients with recent-onset type 1 diabetes: a randomised, doubleblind, placebo-controlled trial. Lancet. 2011; 378(9789):412-419. [PubMed: 21719096]

68. Wong CK, Ho AW, Tong PC, Yeung CY, Chan JC, Kong AP, et al. Aberrant expression of soluble co-stimulatory molecules and adhesion molecules in type 2 diabetic patients with nephropathy. $\mathrm{J}$ Clin Immunol. 2008; 28(1):36-43. [PubMed: 18026823]

69. Krolewski AS, Bonventre JV. New therapies are desperately needed to reduce risk of ESRD in type 1 diabetes, a call to action. Semin Nephrol. 2012 In press.

70. Caramori ML, Fioretto P, Mauer M. Low glomerular filtration rate in normoalbuminuric type 1 diabetic patients: an indicator of more advanced glomerular lesions. Diabetes. 2003; 52(4):10361040. [PubMed: 12663477]

71. Perkins BA, Ficociello LH, Ostrander BE, Silva KH, Weinberg J, Warram JH, et al. Microalbuminuria and the risk for early progressive renal function decline in type 1 diabetes. $\mathrm{J}$ Am Soc Nephrol. 2007; 18(4):1353-1361. [PubMed: 17329575]

72. Premaratne E, MacIsaac RJ, Finch S, Panagiotopoulos S, Ekinci E, Jerums G. Serial measurements of cystatin $\mathrm{C}$ are more accurate than creatinine-based methods in detecting declining renal function in type 1 diabetes. Diabetes Care. 2008; 31(5):971-973. [PubMed: 18319326]

73. Tu YK, Blance A, Clerehugh V, Gilthorpe MS. Statistical power for analyses of changes in randomized controlled trials. J Dent Res. 2005; 84(3):283-287. [PubMed: 15723872]

74. Stevens LA, Greene T, Levey AS. Surrogate end points for clinical trials of kidney disease progression. Clin J Am Soc Nephrol. 2006; 1(4):874-884. [PubMed: 17699300] 


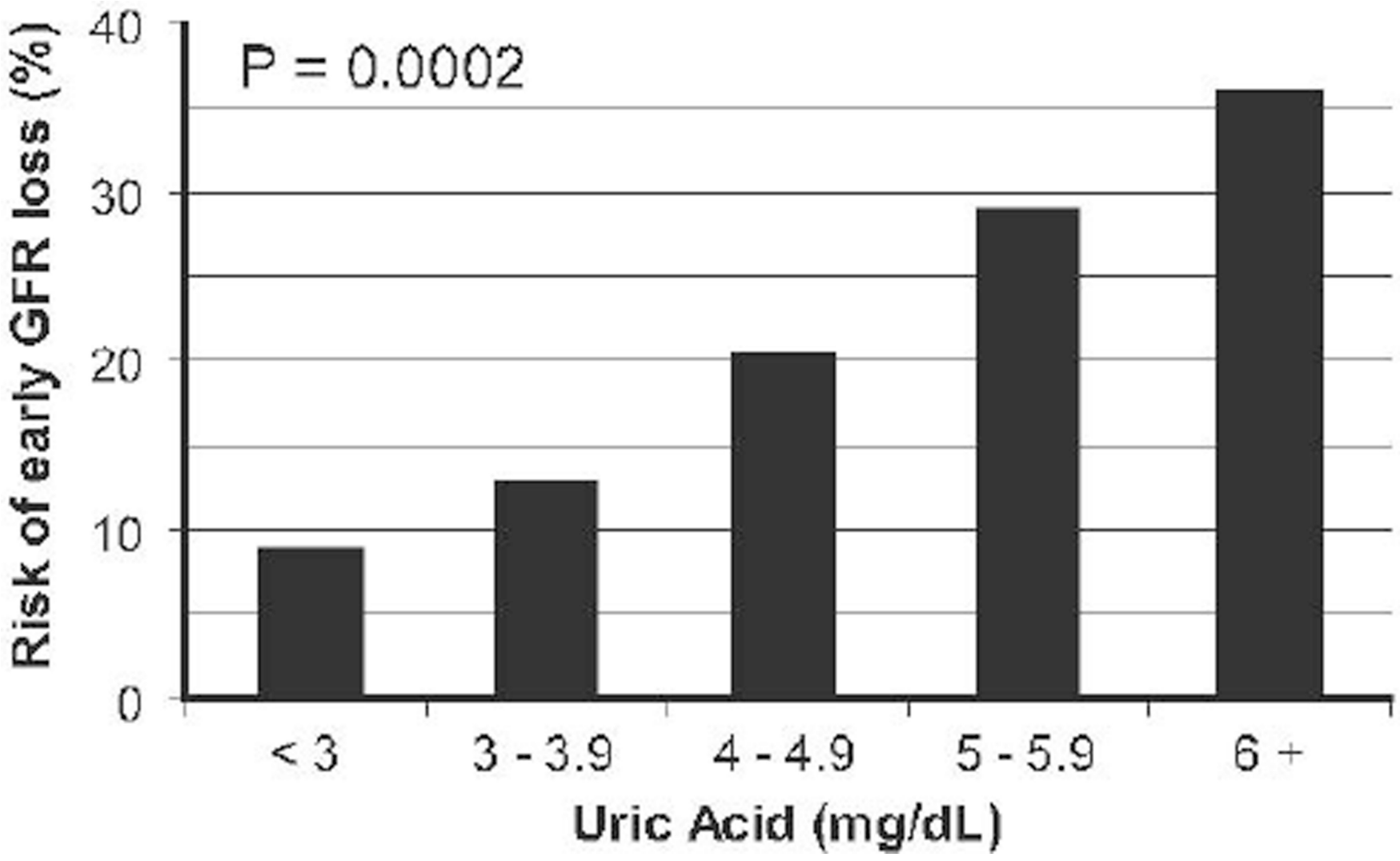

Figure 1.

Risk of early GFR loss in the JKS during 4-6 years of follow-up according to baseline serum UA levels (from Ficociello et al.) 
Type 1 diabetes

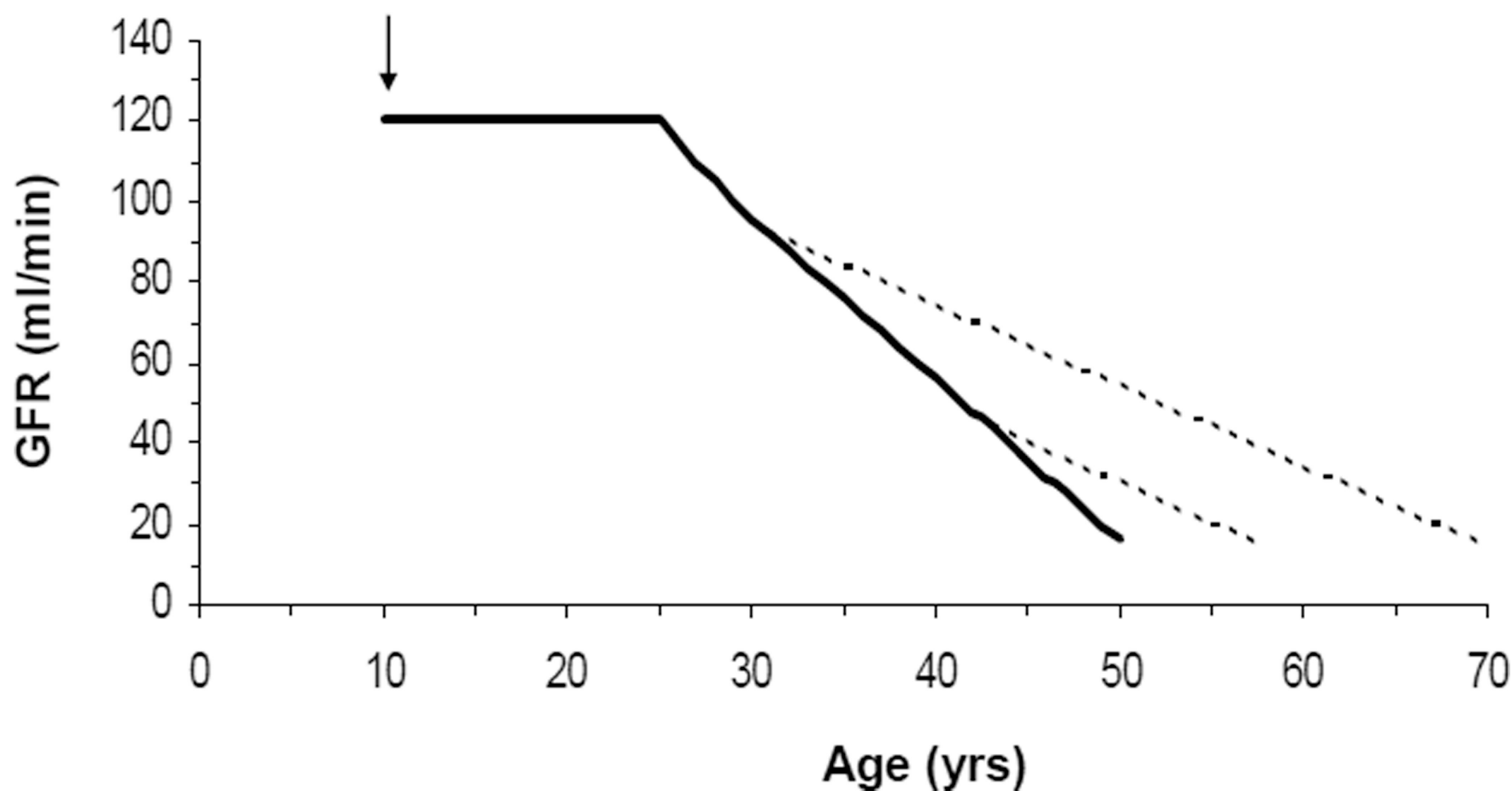

Figure 2.

GFR trajectory of a hypothetical type 1 diabetes patients who developed diabetes at age 10 and started to lose renal function at age 25 at a constant rate of $4 \mathrm{ml} / \mathrm{min}$ per year. The solid line represents the GFR trajectory without treatment, the dotted lines are the trajectories with an intervention that reduce GFR decline from 4 to $2 \mathrm{ml} / \mathrm{min} / \mathrm{year}$ and is started at a GFR of $90 \mathrm{ml} / \mathrm{min}$ or at a GFR of $45 / \mathrm{ml} / \mathrm{min}$. 


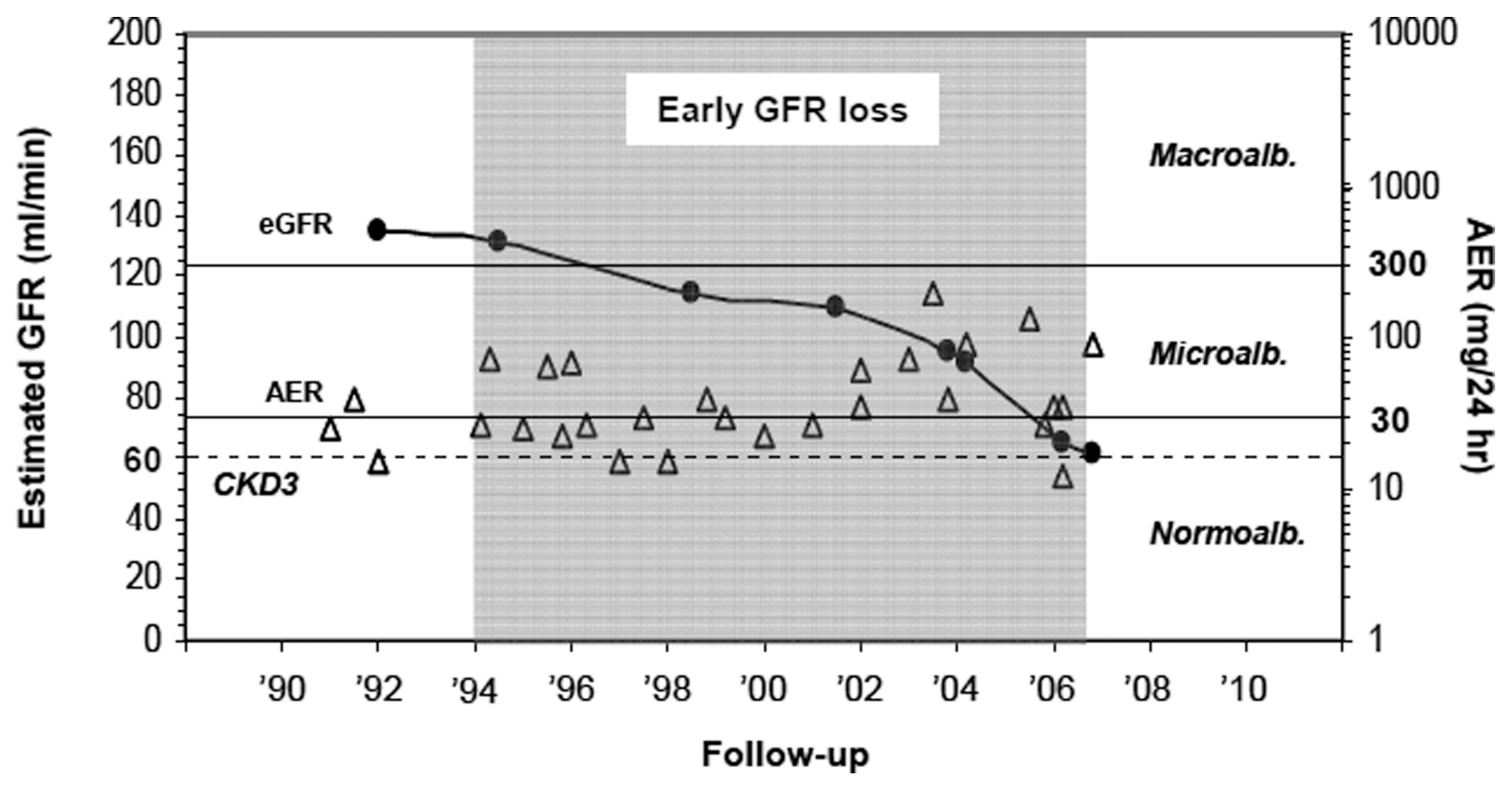

Figure 3.

Course of urinary albumin excretion (triangles) and renal function (circles) over the 14 years preceding the onset of CKD3 in a Joslin type 1 diabetic patient. 


\section{Table 1}

Examples of existing drugs that could have an application in preventing or halting the progression of diabetic nephropathy.

\begin{tabular}{|cccc|}
\hline Drugs & Target & Current indication & Generic available \\
\hline Allopurinol & Uric Acid & Gout, chemotherapy-induced hyperuriciema & Yes \\
\hline Febuxostat & Uric Acid & Gout, chemotherapy-induced hyperuriciema & No \\
\hline Etanercept & TNFa & $\begin{array}{c}\text { Rheumatoid and psoriatic arthritis, plaque psoriasis, } \\
\text { ankylosing spondylitis }\end{array}$ & No \\
\hline Infliximab & TFNa & $\begin{array}{c}\text { Rheumatoid and psoriatic arthritis, plaque psoriasis, } \\
\text { ankylosing spondylitis, Crohn's disease, ulcerative } \\
\text { colitis }\end{array}$ & No \\
\hline Atsttrin & TNFa receptors & Human experimentation in progress. & No \\
\hline Sirolimus & mTor pathway & Prevention of transplant rejection & Yes (Canada) \\
\hline Basiliximab & CD25 & Prevention of transplant rejection & No \\
\hline Mycophenolate mofetil (MMF) & IMPDH (purine biosynthesis) & Antoimmune disorders, prevention of transplant & No \\
\hline rbatacept & CD80/B7.1 & Rheumatoid arthritis & No \\
\hline Belatacept & CD80/B7.1 and CD86/B7.2 & Prevention of transplant rejection & No \\
\hline
\end{tabular}




\section{Table 2}

Clinical Trial with CTLA4-Ig (Abatacept) in kidney/immunological diseases. Abatacept (marketed as Orencia) is a fusion protien generated with an immunoglobulin fused to the extracellular domain of CTLA4 and capable of stable binding to B7.1/CD80, thus blocking its activation.

\begin{tabular}{|c|c|c|}
\hline Study/Identifier & Purpose & Status/PI \\
\hline $\begin{array}{l}\text { Efficacy and Safety Study of } \\
\text { Abatacept to Treat Lupus } \\
\text { Nephritis } \\
\text { NCT00430677 }\end{array}$ & $\begin{array}{l}\text { The purpose of this clinical research study is to learn if abatacept } \\
\text { treatment of patients with active lupus nephritis who are also taking } \\
\text { mycophenolate mofetil (MMF) and steroid as part of this study will } \\
\text { control the nephritis despite a protocol-defined steroid taper; the } \\
\text { endpoint is "confirmed complete renal response", a composite } \\
\text { including stabilization or improvement of renal function, } \\
\text { improvement of proteinuria, and improvement of urinary sediment. } \\
\text { The safety of this treatment will also be studied }\end{array}$ & Ongoing Bristol-Myers Squibb \\
\hline $\begin{array}{l}\text { Abatacept and } \\
\text { Cyclophosphamide } \\
\text { Combination Therapy for } \\
\text { Lupus Nephritis (ACCESS) } \\
\text { NCT00774852 }\end{array}$ & $\begin{array}{l}\text { This study is for people with lupus who have developed } \\
\text { complications in their kidneys, or lupus nephritis. The study will } \\
\text { determine whether adding the experimental medication abatacept to } \\
\text { standard cyclophosphamide therapy is more effective in improving } \\
\text { lupus nephritis than standard cyclophosphamide therapy by itself }\end{array}$ & $\begin{array}{l}\text { Ongoing David wofsy,, University of } \\
\text { California, San Francisco Betty } \\
\text { Diamond, MDFeinstein Institute }\end{array}$ \\
\hline $\begin{array}{l}\text { Abatacept in Treating Adults } \\
\text { With Mild Relapsing } \\
\text { Wegener's Granulomatosis } \\
\text { NCT00468208 }\end{array}$ & $\begin{array}{l}\text { Wegener's granulomatosis (WG) is a rare disease that causes } \\
\text { inflammation of blood vessele, or vasculitis. It may involve many } \\
\text { different parts of the body, but typically affects the upper and lower } \\
\text { respiratory tract and kidneys. The purpose of this study is to } \\
\text { determine the safety and effectiveness of the medication abatacept } \\
\text { in treating adults with mild relapsing WG }\end{array}$ & $\begin{array}{c}\text { Ongoing } \\
\text { Carol A. Langford, The Cleveland } \\
\text { Clinic Peter A. Merkel, Boston } \\
\text { University }\end{array}$ \\
\hline $\begin{array}{l}\text { Abatacept in ANCA } \\
\text { Associated Vasculitis } \\
\text { (ABAVAS) } \\
\text { NCT00482066 }\end{array}$ & $\begin{array}{l}\text { The purpose of this study is to investigate whether abatacept can } \\
\text { prevent relapse in patients with ANCA associated vasculitis(AAV). } \\
\text { This is a randomised double blined placebo controlled trial }\end{array}$ & $\begin{array}{l}\text { Terminated Alan Salama Imperial } \\
\text { College London }\end{array}$ \\
\hline $\begin{array}{l}\text { Intravenous CTLA4-Ig } \\
\text { Treatment in Recent Onset } \\
\text { Type 1 Diabetes Mellitus } \\
\text { NCT00505375 }\end{array}$ & $\begin{array}{c}\text { The purpose of this study is to determine whether treatment with } \\
\text { CTLA4-Ig (Abatacept) in individuals with new onset T1DM will } \\
\text { improve insulin secretion (C-peptide production) compared to } \\
\text { placebo }\end{array}$ & $\begin{array}{l}\text { Ongoing Tihamer Orban, joslin } \\
\text { Diabetes Center }\end{array}$ \\
\hline $\begin{array}{l}\text { Islet Transplantation Using } \\
\text { Abatacept } \\
\text { NCT00276250 }\end{array}$ & $\begin{array}{l}\text { Islet transplantation in type } 1 \text { diabetices with hypoglycemic } \\
\text { unawareness using abatacept as a part of a novel calcineurin- } \\
\text { inhibitor-sparing immunosuppressive regimen. }\end{array}$ & $\begin{array}{l}\text { Ongoing Christian P Larsen/Thomas C } \\
\text { Pearson Emory University }\end{array}$ \\
\hline
\end{tabular}

